\title{
Morphological and morph metric study of the mandible in the local Rabbits
}

\section{(Oryctolagus Cunicuius) \\ Qismah Modhafar Salih}

Department of Anatomy, College of Veterinary Medicine, Mosul University, Iraq.

E-mail: Qismah_m@yahoo.com

Accepted: 24/6/2015

\section{Summary}

Eleven adult local rabbits (6 female and 5male) were used for this study. The mandible were prepared to study the gross anatomical features. The main gross characteristics feature of the local rabbits mandible the ramus forms a broad, thin and flat plate, the surface of the ramus is greatly increased in its posteroventral portion to form the angle or angular process. The articular surface is elongated and carry on its caudodorsal end a slightly oblique condyloid process, this process in rabbit is raised much above the planes of the molar table and has a prolonged aspect in a longitudinal plan. In front of the shallow mandibular notch, the coronoid process is short and blunt process situated in front of mandibular notch. In the rabbit mandible the alveoli for the canine teeth were absent resulting in a large diastema Mandibular foramen situated on the medial surface immediately behind the last molar. There is a large retroalveolr foramen. The female local rabbit showed significant greater measurement than the male.

Keywords: Morphology, Mandible, Rabbits.

\section{Introduction}

The domestic rabbit is used for many purposes including biomedical research, meat and fur and there has recently been a marked increase in its popularity as a companion animal and it has become the third most popular mammalian pet in the U.K after dog and cat, consequently there has been an increase in level of the veterinary care demanded by owners for this species (1). The mandible or lower jaw bone is the largest and only mobile bone of the mammalian skull, it hold the lower teeth, the right and left half united at the mandibular symphaysis (2). The masticators muscles are closely related to the mandible, so any changes as a result of intrinsic or extrinsic causes it will effect on muscles and bones and phenotypic properties of these tissues (3 and 4). The morphology of mandible amongst other factors affects preference made for different plant species (5). The regional (clinical) anatomy one of the most important branches of anatomy which helps the clinicians as well as surgeons to visualize details of structures relevant to case at hand (1 and 6 ). The mandible has been osteometrically examined and described in detail in different animals (6-12) they study the mandible of the ruminants, while $(13-15)$ examined the mandible of mouse and rat, (16 and 17) in donkey and horse, in carnivores (18-20) in Ostrich (21).The studies on the mandible of the local rabbits were scarce in the literature (15 and 22-28). The goal of the present study was to investigate the mandible in local breed rabbits and to contribute baseline research information of the species, and to evaluate some morph metric parameter and to ascertain presence of sexual dimorphism of the mandible of local rabbits.

\section{Materials and Methods}

Eleven adult rabbits without any apparent skeletal disorders were used (6 males and 5 females).The animals were slaughtered at the Atlanto-occipital joint and the mandible were prepared by using the Enzyme-active detergent technique (29). The mandibular measurement was carried out in 14 items with digital varinier caliper. The measurement and landmarks were based on (28 and 30). The measurements, abbreviation and definition were arranged in Table (1) and shown in (Fig. 1, 2 and 3). The nomenclatures in this study was adopted according to (Nomina Anatomica Veterinaria (2005) and (American Veterinary Dental Nomenclature (2012) AVDC Nomenclature Committee. The statistical analysis: the paired samples T-test analyzing method was used with programs of statistical analysis system (SAS). 




Figure, 1: The mandible bone of the local rabbit showing the measurements which reported in (Table, 1). (f): retroalevolar foramen. Gonion (GN) a point along the rounded postero-inferior corner of the mandible between the ramus and the body. Gondylion (CD): the most lateral point on mandibular condoyle (paired). Breadth of the mandibular body: (BMB) maximum breadth measured in the region of the mental foramen. Bigonial width (BW): direct distance between right and left gonion (gn). Bicondylar breadth (BCB): direct distance between the most lateral points on the two condyles (CD). Distemal length (DL): distance between the incisors to the first molar. Length of cheek teeth row (LCHR).

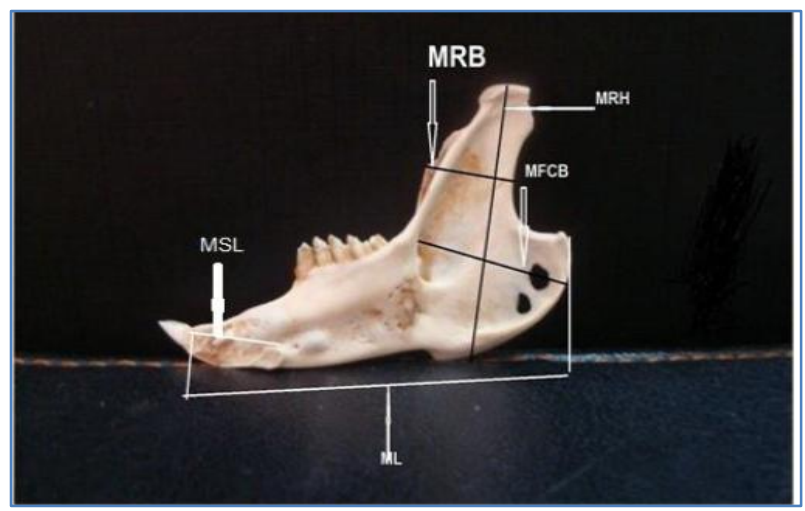

Figure, 2: the medial surface of the mandible of the local rabbit showing the measurements which reported in (Table, 1). Minimum ramus breadth (MRB): least breadth of the mandibular ramus. Mandibular symphaysis length (MSL). Mandibular foramen caudal border (MFCB): the distance between mandibular foramen and caudal border. Mandibular length (ML): distance of the anterior of the alveoli of incisor to the posterior border of the ramus. Ramus height (MRH): direct distance from the highest point on the mandibular condyle. to the gonion (gn).

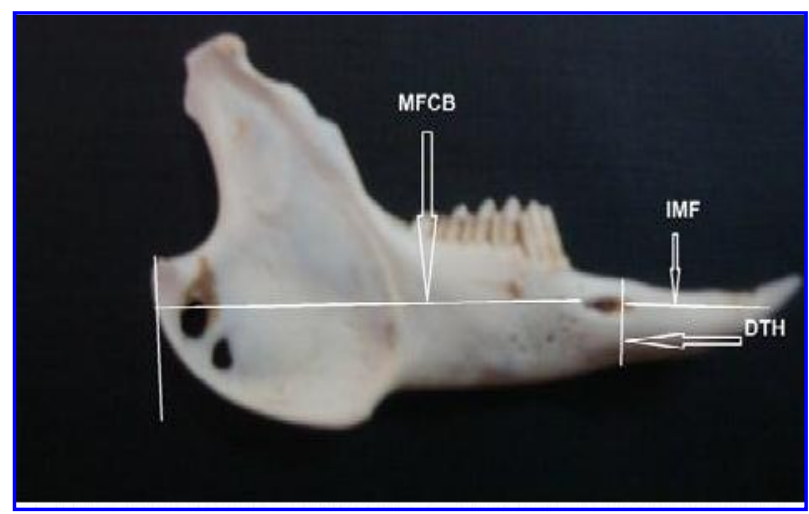

Figure, 3: The lateral surface of mandible of local rabbit showing the measurements reported in (Table, 1). Distamal thickness (DTH): Distance between the dorsal and ventral Distamal border. Mandibular foramen caudal border (MFCB): the distance between mandibular foramen and caudal border. Incisor-mental (IMF): Shortest distance from incisor to mental F.
Results and Discussion

Grossly, the mandible composed of two portions united interiorly by the symphysis each half comprises a horizontal portion, the body of the mandible and a posterior vertical portion the ramus. The body bears on its dorsal margin the alveoli of lower teeth (interiorly pair incisor and five alveoli for molar teeth (two premolars and three molar teeth)). The mandible of the local rabbit characterized by having long diastema. The ramus forms a broad, thin and flat plate, (Fig. 4, e) the surface of the ramus is greatly increased in its postero ventral portion to form the angle or angular process (Fig. 4, d). This results is in agreement with (27) in rabbit, (14) also mention that the angular process was present in African giant rat, (16) in Golden Jackal and (20) in cat. The articular surface is elongated and carry on its caudodorsal end a slightly oblique condyloid process (Fig. 4, a), this process in rabbit raised much above the planes of the molar table and has prolonged aspect in a longitudinal plan .In front of the shallow mandibular notch (Fig. 4, $\mathrm{f}$ ), the coronoid process is short and blunt process situated in front of mandibular notch (Fig. 4,b), this result was in agreement (15 and 27).

In accordance with (27) in the rabbit mandible the alveoli for the canine teeth were absent resulting in a large diastema. On other hands (7) mentioned that the coronoid process and the angle of the mandible were not well developed in Lesser Mouse Deer. The mandibular foramen immediately behind the last molar tooth at the medial surface, there is a large retroalveolar foramen passes from the dorsal border to the medial surface of the mandible (Fig. 1, f). The researchers (27) were agreed with our results that the retroaleovler foramen peculiar to rabbit mandible which situated on the cranial border of the ramus just caudal to the last tooth.

The morphmetrical results: The mean value and standard deviation of measurement of the mandible were arranged in (Table, 1). The (BMB, BW, HMB, BCB, MRB, MAD, IMF, MCB, MSL, DTH) measurement of the mandible show no significant difference between male and female local rabbits. The significant sexual differences of the local rabbit mandible appear in (ML, MRH, DL) at 
$5 \%$ and (MFCB) at $1 \%$ measurements, the female showed significantly greater value than the male.

Table, 1: The measurements of the mandible of the local rabbits.

\begin{tabular}{|c|c|c|c|}
\hline Measurements & Gender & Mean \pm S.E & $\begin{array}{c}\text { Sig. } \\
\text { (2-tailed) }\end{array}$ \\
\hline M.L & $\begin{array}{c}\text { Male } \\
\text { Female }\end{array}$ & $\begin{array}{l}4.648 \pm 0.153 \\
5.248 \pm 0.133\end{array}$ & $0.011 * *$ \\
\hline BMB & $\begin{array}{c}\text { Male } \\
\text { Female }\end{array}$ & $\begin{array}{l}0.955 \pm 0.143 \\
1.068 \pm 0.140\end{array}$ & 0.471 \\
\hline BW & $\begin{array}{c}\text { Male } \\
\text { Female }\end{array}$ & $\begin{array}{l}2.910 \pm 0.173 \\
3.174 \pm 0.084\end{array}$ & 0.473 \\
\hline HMB & $\begin{array}{c}\text { Male } \\
\text { Female }\end{array}$ & $\begin{array}{l}1.215 \pm 0.476 \\
1.320 \pm 0.589\end{array}$ & 0.126 \\
\hline BCB & $\begin{array}{c}\text { Male } \\
\text { Female }\end{array}$ & $\begin{array}{l}2.695 \pm 0.938 \\
2.968 \pm 0.079\end{array}$ & 0.137 \\
\hline MRB & $\begin{array}{l}\text { Male } \\
\text { Female }\end{array}$ & $\begin{array}{l}1.246 \pm 0.053 \\
1.330 \pm 0.463\end{array}$ & 0.219 \\
\hline MRH & $\begin{array}{c}\text { Male } \\
\text { Female }\end{array}$ & $\begin{array}{l}2.881 \pm 0.089 \\
3.252 \pm 0.020\end{array}$ & $0.02 * *$ \\
\hline MAD & $\begin{array}{c}\text { Male } \\
\text { Female }\end{array}$ & $\begin{array}{l}1.363 \pm 0.070 \\
1.358 \pm 0.035\end{array}$ & 0.836 \\
\hline IMF & $\begin{array}{l}\text { Male } \\
\text { Female }\end{array}$ & $\begin{array}{l}1.201 \pm 0.017 \\
1.202 \pm 0.032\end{array}$ & 0.777 \\
\hline MCB & $\begin{array}{l}\text { Male } \\
\text { Female }\end{array}$ & $\begin{array}{l}3.733 \pm 0.118 \\
3.490 \pm 0.060\end{array}$ & 0.339 \\
\hline DL & $\begin{array}{c}\text { Male } \\
\text { Female }\end{array}$ & $\begin{array}{l}1.485 \pm 0.022 \\
1.584 \pm 0.043\end{array}$ & $0.017 * *$ \\
\hline MFCB & $\begin{array}{c}\text { Male } \\
\text { Female }\end{array}$ & $\begin{array}{l}1.655 \pm 0.109 \\
2.178 \pm 0.098\end{array}$ & $0.042 *$ \\
\hline MSL & $\begin{array}{c}\text { Male } \\
\text { Female }\end{array}$ & $\begin{array}{l}0.780 \pm 0.043 \\
0.838 \pm 0.021\end{array}$ & 0.194 \\
\hline DTH & $\begin{array}{c}\text { Male } \\
\text { Female }\end{array}$ & $\begin{array}{l}0.536 \pm 0.022 \\
0.950 \pm 0.015\end{array}$ & 0.554 \\
\hline
\end{tabular}

Mandibular length (ML): distance of the anterior of the alveoli of incisor to the posterior border of the ramus. Breadth of the mandibular body (BMB): maximum breadth measured in the region of the mental foramen. Bigonial width $(\mathrm{BW})$ : direct distance between right and left gonion (gn). Height of the mandibular body (HMB): direct distance from the alveolar process of the molar to the ventral border of the mandible. Bicondylar breadth (BCB): direct distance between the most lateral points on the two condyles (CD). Minimum ramus breadth (MRB): least breadth of the mandibular ramus. Ramus height (MRH): direct distance from the highest point on the mandibular condyle to the gonion (gn). Molar arch distance (MAD): distance from the anterior to posterior molar. Incisor- mental (IMF): shortest distance from incisor to mental F. Mental -caudal mandibular border (MCB): distance from mental F.to caudal border. Distemal length (DL): distance between the incisors to the first molar. Mandibular foramen caudal border (MFCB): the distance between mandibular foramen and caudal border. Mandibular symphaysis length (MSL). Distamal thickness (DTH): Distance between the dorsal and ventral Distamal border.

Other authors (12) studied the mandible of camel in different region of north Nigeria and reported that no significant differences observed in most mandibular indices in adult camels between sexes, and (28) provide a mandible measurement of New Zealand white rabbit which were similar to the results of domestic rabbits, also (16) reported that the mandibular data of Iranian native donkeys were lower than the data obtained for horse. The anatomy of Persian cat mandible and reported that data of this cat were similar to the cat with round-shaped skull but were relatively different from findings on the cats with triangular or cuneiform skulls (18). In Iraqi sheep (9) reported that there were a significant variation present between the three Iraqi sheep in diastema length, diastema height, notch height, body height, jaw length. While (30) study the mandible in Indian population and confirm that the mandible ramus can be used for sexing, while (10) predicated that the mandibular corpus bone can be used to compare between strains, also (22) used mandible to identify the strains of the rabbits and (31) used the mandibular canines in sex determination.

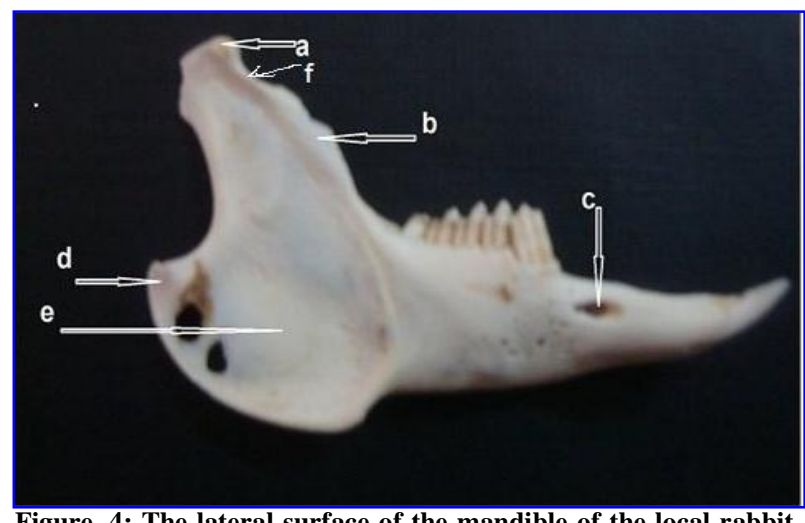

Figure, 4: The lateral surface of the mandible of the local rabbit. (a) condyloid process (b)coronoid process (c) mental foramen (d)angular process (e) ramus (f) mandibular notch.

\section{References}

1. Louei, M. A. (2013). Applied anatomy of the rabbits skull and its clinical application during regional anesthesia. Global Veterinaria. 10(6): 653-657.

2. Pasquini, C.; Spurgeon, T. and Psquini, S. (1997). Anatomy of domestic animals systemic and regional reproach 3rd addition Sudz publishing. $3^{\text {rd }}$ ed. Pp: 44-45.

3. Grunheid, T. M.; Brugman, P. M.; Zentner, A. and Hangenbach, E. J. (2010). Change in Rabbits jaw muscle activity parameters in 
response to reduce masticator load. $\mathrm{J}$. Experim. Biol. 213: 775-781.

4. Jong, W. C.; Korfage, A. M. and Laangenbach, E. J. (2011). The Role of masticatory muscle in the continuous loading of the mandible J, Anat., 218: 635-636.

5. Yahaya, A.; Olopade, J. O.; Kwari, H. D. and Hambali, I. U. (2012). Some aspects of the Maxillofacial and Mandibular Anatomy of Camels (Camelus Domedaries) in Nigeria. J. Morphol. Sci., 29(3):140-143.

6. Karimi, I.; Hadipour, M.; Nikbakht, P. and Motamedi, S. H. (2012). The Lower jaw bone of Mehraban sheep: adscription morphometric approach. World Vet. J., 2(4): 57-60.

7. Endo, S. T. H.; Rerkamnuaychoke, W.; Hondo, E.; Agungpriyan, J.; Kitamura, N.; Kurchmaru, M.; Kimura, J.; Hayashi, Y.; Nishida, T. and Yamada, J. (1998). An Ostemetrical study of the cranium and mandible of the Lesser Mouse Deer (chevrotain)Tragulus Javanicus. J. Vet. Med. Sci., 60(10): 1097-1105.

8. Olopade, J. O. and Onwuka, S. K. (2005). Some Aspects of the clinical anatomy of the mandibular and maxillofacial regions of the West African Dwarf Goat in Nigeria. Int. J. Morph., 23(1): 33-36.

9. Salih, K. M. and Ahamad, N. S. (2006). Morphological and morpho metrical study of the mandible bone of the Native Sheep. Conferences 4th of Vet. Med. Coll. Unvi. Mosul, Iraq. 2(2): 517-525.

10. Williams, S. H.; Vinyand, CH. J.; Wall, CH. E. and Hylander, W. L. (2009). Mandibular Corpus bone Strain in Goats and Alpacus Implications for understanding the Biomechanics of Mandibular form in Salenodont. J. Anat., 214: 65-78.

11. Mejbah uddin, M.; Ahmed, S. S. U.; Islam, KH. N. and Islam, MD. M. (2009). Clinical Anatomy of the Head Region of the Black Bengal goat in Bangladesh. Int. J. Morph., 27(4): 1269-1273.

12. Yahaya, A.; Olopde, J. O. and Kwari, H. D. (2011). Clinical Implication of Craniometric indices of the one Humped Camel (Camolus Dromedarius) to Oral Health and Clinical Regional Anesthesia of the head. J. Vet. Anat., 4(1): 19-31.
13. Atchey, W. R.; Herning, S. W.; Riska, B.; Plummer, A. A. (1984). Effects of the Muscular dysgenesis gene development stability in the mouse mandible. J. Craniofac. Genet. Dev. Biol., 4(3): 179-89.

14. Olude, M. A. and Olopade, J. O. (2010). Morpho metric studies of the Axial Skeleton of the African Giant Rat (Cricetomys gambianus, waterhouse) part (1) skull Typology. J. Vet. Anat., 3 (2): 1-12.

15. Spatau, C.; Spatau, M.; Vulpe, V.; Lazar, M. (2013). The peculiarities of the masticator muscles in rodent. Arq. Brras. Med. Vet. Zootec., 65, (3): 749-756.

16. Louei, M. A. (2013). Anatomy of the mandibular and maxillofacial region of the Iranian native donkeys and its clinical implications during regional Anesthesia. Global Veterinaria 10(6): 658-662.

17. Louei, M. A. (2013). Some aspect of clinical anatomy of head region of the Casplan Miniture horse and its clinical value during Regional anesthesia .Global Veterinaria 10(2): 214-218.

18. Loue, M. A. (2013). Anatomical study of the skull of the adult dogs and its clinical value during regional anesthesia. Global Veterinaria. 10(4): 459-463.

19. Louei, M. A. (2013). Macro-anatomical investigation of the skull of Golden Jackal (Canis Aureus) and its clinical application during regional anesthesia .Global Veterinaria 10(5): 547-550.

20. Louei Momfared, A. (2013). Anatomy of the Pasian Cat's skull and its clinical value during regional anesthesia. Global Veterinaria. 10(5): 551-555.

21. Rayfield, E. J. (2011). Strain in the ostrich mandible during stimulated pecking and validation of specimen specific finite element models. J. Anat. 218: 47-58.

22. Goto, N.; Watanabe, K.; Umezewa, H.; Yazawa, H. and Kuramasu, S. (1987). Morpho metrical observations on the mandible of five strains of rabbits and Strain identification using mandible Measurements. Lab. Anim., 21: 188-194.

23. Abreu, A.T.; Veeck, E. B. and Costa, N. P. (2006). Morphometric methods to evaluate craniofacial growth study in rabbit. dentomaxillofacial Radiol. 35: 83087. 
24. Gandur, I. V.; Walton, V. T.; Lobato, P. C.; Devaces, V. L. and Manzanares, M. C. (2011). Mandible measurement and dental midline deviation after alveolar nerve transaction $\mathrm{I} \mathrm{n}$ growing rabbits. Inter. $\mathrm{J}$. Morpho. 29(1): 52-56.

25. Jong, W. C.; Karfage, A. and Langenbach, E. J. (2011). The Role of masticatory muscles in continuous loading of the mandible. J. Anat., 218: 625-636.

26. Grunheid, T.; Brugman, P.; Zentner, A. and Langenbach, E. J. (2011). Changes in rabbit jaw muscle activity parameters in response to reduced masticatory load. J. Experim. Biol., 213: 775-781.

27. Farag, F. M.; Daghash, S. M. and Hagrass, S. M. (2012). Anatomical studies on the skull of the domestic rabbit (Oryctologus Cuniculus) with special reference to the hyoid apparatus. J. Vet. Anat., 5 (2): 49-70.

28. Louei, M. A. (2013). Applied anatomy of the rabbits skull and its clinical application during regional anesthesia. Global Veterinaria. 10(6): 653-657.

29. Mooney, P. K.; Kraurs, E. M. and Bardach, J. (1982). Skull preparation using the enzymeactive detergent technique. Anat. Record. 202: 125-129.

30. Pokhrel, R. and Bhatngar, R. (2013). Sexing of mandible using ramus and condyle in Indian population adiscriminant function analysis. Eur. J. Ana., 17(1): 39-43.

31. Kaushal, S.; Patnaik, V. V. G. and Agnihotri, G. (2013). Mandibular canines in sex determination. J. Anat. Sic. India. 52(2): 119124.

\section{در استة شُكلية وقياسية لعظم القك في الأر انب المحلية \\ قسمة مظفر صالح \\ فرع التشريح، كلية الطب البيطري، جامعة الموصل، العراق. \\ E-mail: Qismah_m@yahoo.com \\ الخلاصة}

استعمل في هذه الدر اسة أحد عشر أرنب محلي (6 اناث و5 ذكور) بالغة. حُضِّرَ الفلك للدر اسة التشريحية العيانية والقياسات

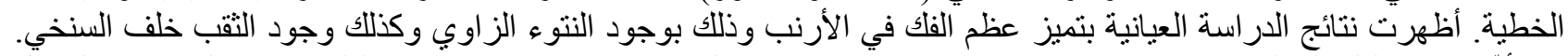



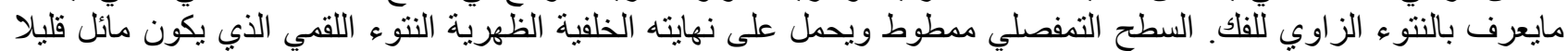

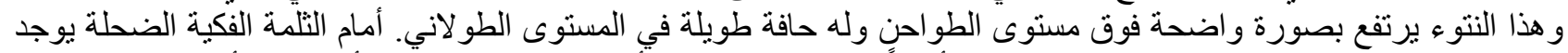

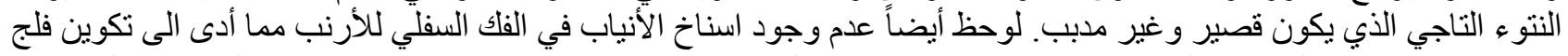

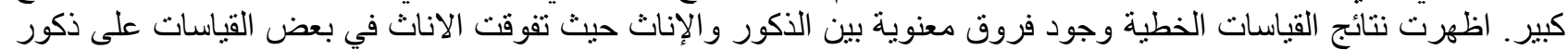
الأر انب المحلية. الكلمات المفتاحية: شكلية، الفحك، الأرانب. 